\title{
Temporomandibular disorder and serum levels of progesterone and estrogen:
}

\section{Systematic review}

\author{
Disfunção temporomandibular e níveis séricos de progesterona e estrogênio: Revisão sistemática \\ Disfunción Temporomandibular y niveles de progesterona y estrógeno en suero: Revisión
}

\section{sistemática}

Received: 04/30/2021 | Reviewed: 05/08/2021 | Accept: 05/09/2021 | Published: 05/28/2021

\author{
Ricardo Felipe Ferreira da Silva \\ ORCID: https://orcid.org/0000-0002-4493-1128 \\ Universidade Potiguar, Brasil \\ E-mail: felipeferreiraodontologia@gmail.com \\ Irami Araújo-Filho \\ ORCID: https://orcid.org/0000-0003-2471-7447 \\ Universidade Potiguar, Brasil \\ E-mail: irami.filho@uol.com.br \\ Amália Cinthia Meneses do Rego \\ ORCID: https://orcid.org/0000-0002-0575-3752 \\ Universidade Potiguar, Brasil \\ E-mail: amaliarego@unp.br \\ Bruna Dantas da Silva \\ ORCID: https://orcid.org/0000-0002-3617-2897 \\ Universidade Estadual da Paraíba, Brasil \\ E-mail: dans.bruna@gmail.com \\ José Renato Cavalcanti Queiroz \\ ORCID: https://orcid.org/0000-0001-8573-0288 \\ Universidade Potiguar, Brasil \\ E-mail: josrenatocq@ hotmail.com \\ Débora Michelle Gonçalves de Amorim \\ ORCID: https://orcid.org/ 0000-0001-7868-7015 \\ Universidade Potiguar, Brasil \\ E-mail: debora.amorim@unp.br
}

\begin{abstract}
Temporomandibular Disorder (TMD) is a pathology of the stomatognathic system characterized by a set of clinical disorders that includes a temporomandibular joint, a masticatory musculature and associated structures. It is the most common orofacial pain condition of non-dental origin and which is increasing among adults in the age group between 18 and 45 years with a not well defined etiology, mainly not with regard to its higher prevalence in women than men. The present study aimed to evaluate the literature if there is a relationship between the levels of progesterone and estrogen with the clinical manifestations of TMD. The systematic search was carried out in the following electronic databases: PubMed, Web of Science, SciELO, and LILACS, Scopus, Embase and Google Scholar in addition to a complementary manual search of cross-references of original articles. There was no time restriction. The descriptors used were "TMD" or "TMJ" and "progesterone" and "estrogen". Initially, 132 articles were found, were 15 presented the eligibility criteria to be read in full. In the end, 4 studies were included in the review. The conclusion was that most studies relate the variations of progesterone and estrogen to the symptoms of the disease; however, there are differences between them. Thus, it is recommended to carry out studies that analyze this relationship, leading to hormonal fluctuations ranging from reproductive age to post-menopause.
\end{abstract}

Keywords: Temporomandibular dysfunction; Orofacial pain; Estrogen; Progesterone.

\section{Resumo}

A Disfunção Temporomandibular (DTM) é uma patologia do sistema estomatognático caracterizada por um conjunto de desordens clínicos que inclui a articulação temporomandibular, a musculatura mastigatória e estruturas associadas. É a condição de dor orofacial mais comum de origem não-dentária e que vem aumentando entre adultos na faixa etária entre 18 e 45 anos com etiologia não bem definida, principalmente no que diz respeito à sua maior prevalência em mulheres que homens. O presente estudo buscou avaliar através da literatura se há relação entre os níveis de progesterona e estrogênio com as manifestações clínicas da DTM. A busca sistemática foi realizada nas seguintes bases eletrônicas: PubMed, Web of Science, SciELO e LILACS, Scopus, Embase e Google Scholar, além de busca manual complementar de referências cruzadas de artigos originais. Não houve restrição de tempo. Os descritores 
utilizados foram "TMD" ou "TMJ" e "progesterone" e "estrogen". Inicialmente, 132 artigos foram encontrados, onde 15 apresentavam os critérios de elegibilidade para ser realizada a leitura na íntegra. Ao final, 4 estudos foram incluídos na revisão. Concluiu-se que a maioria dos estudos relacionaram as variações de progesterona e estrogênio com a sintomatologia da doença, entretanto, há divergências entre eles. Dessa forma, recomenda-se a realização de estudos que analisem essa relação levando as flutuações hormonais que vão desde a idade reprodutiva até a pósmenopausa.

Palavras-chave: Disfunção temporomandibular; Dor orofacial; Estrogênio; Progesterona.

\section{Resumen}

La disfunción temporomandibular (DTM) es una patología del sistema estomatognático caracterizada por un conjunto de trastornos clínicos que incluye la articulación temporomandibular, los músculos masticatorios y las estructuras asociadas. Es la condición de dolor orofacial de origen no dental más común y ha ido aumentando entre los adultos en el grupo de edad entre 18 y 45 años con una etiología no bien definida, principalmente en lo que respecta a su mayor prevalencia en mujeres que en hombres. El presente estudio buscó evaluar a través de la literatura si existe una relación entre los niveles de progesterona y estrógeno con las manifestaciones clínicas de TTM. La búsqueda sistemática se realizó en las siguientes bases de datos electrónicas: PubMed, Web of Science, SciELO y LILACS, Scopus, Embase y Google Scholar, además de una búsqueda manual complementaria de referencias cruzadas de artículos originales. No hubo restricción de tiempo. Los descriptores utilizados fueron "TMD" o "TMJ" y "progesterona" y "estrógeno". Inicialmente se encontraron 132 artículos, de los cuales 15 presentaron los criterios de elegibilidad para ser leídos en su totalidad. Al final, se incluyeron 4 estudios en la revisión. Se concluyó que la mayoría de los estudios relacionan las variaciones de progesterona y estrógeno con los síntomas de la enfermedad, sin embargo, existen divergencias entre ellos. Por ello, se recomienda realizar estudios que analicen esta relación, tomando fluctuaciones hormonales que van desde la edad reproductiva hasta la posmenopausia.

Palabras clave: Disfunción temporomandibular; Dolor orofacial; Estrógeno; Progesterona.

\section{Introduction}

Temporomandibular Dysfunction (TMD) is the term designated for a set of clinical disorders that includes conditions of the temporomandibular joint, masticatory muscles, and associated structures (Bartley \& Fillingim, 2013). The symptoms described include limitation in mandibular movement, generalized and joint myofascial pain, presence of noise associated with the function, and functional limitation, locking or deviation of the mandible opening (De Rossi, Greenberg \& Steinkeler, 2014). Its exact etiology is not yet well defined, but several studies related to stress and anxiety (Reiter et al., 2015; Wieckiewicz et al., 2014), as well as age, occlusion and parafunction (Shedden et al., 2012), systemic inflammatory pathologies (Wahid et al., 2014), such as rheumatoid arthritis (Benoliel \& Sharav, 2010; Yu et al., 2009) and gender (De Rossi, Greenberg \& Steinkeler, 2014; Yu et al., 2009).

It is the most common orofacial pain condition of non-dental origin, which has been increasing over time, affecting mainly the age group between 18-45 years, with a higher prevalence in women (in the proportion of 3: 1) than men. About $80 \%$ of treated patients are women. The pre-menopause period has a greater number of cases than the post-menopause (Bartley \& Fillingim, 2013; Joseph et al., 2019; Stinson et al., 2019; Maurer et al., 2016). The reason for this difference between genders is not clear, but it supports the study of female hormones - estrogen and progesterone - as a predisposing factor to the development and severity of the disease. In addition, clinical signs such as the presence of painful symptoms after puberty, the lower prevalence in post-menopausal years, and the reduction of symptoms during pregnancy reinforce this hypothesis (Wahid et al., 2014; De Rossi, Greenberg \& Steinkeler, 2014; Yu et al., 2009).

Estrogen is a representative steroid hormone and is associated with several functions in the body systems in both sexes, including the development, restitution, and metabolism of the temporomandibular region and related structures, as well as pain mediation through the presence of its receptors (Kou et al., 2011; Lu et al., 2012; Torres-Chávez et al., 2012). Studies show the high affinity of receptors present in the ATM, which influence the function and maintenance of these structures. Variations in estrogen hormone levels are able to promote sagging joints, especially during pregnancy, and this is believed to have a role in the development of some disorders (Patil et al., 2015). Estrogens act on bone, promoting osteoclastic activity, 
and cartilage influencing its renewal (Landi et al., 2005). Inflammatory modulation occurs through the interaction between inflammatory mediators such as histamine, serotonin, platelet-activating factor, and nitric oxide, which act centrally and regionally, influencing bone, joint, and muscle pain (Patil et al., 2015).

Progesterone is related to inflammatory and immunological modulation. Its reduction can induce an exacerbated inflammatory response and its maintenance at normal levels demonstrates a reduction in edema and pain in inflammatory diseases (Patil et al., 2015; Xue et al., 2017). Animal studies have shown a strong relationship between high levels of estrogen and inflammation of the temporomandibular joint through cytokine production (Kou et al., 2011) and an improvement in symptoms caused by increased levels of progesterone (Xue et al., 2017).

In addition, estrogens and progesterone can affect the content and characteristics of collagen fibers, both hormones, alone or in combination, increase the type III collagen content and lead to a decrease in type I / III collagen ratio (Madani $e t$ al., 2013). Immunohistochemical analyzes demonstrated the presence of estrogen and progesterone receptors in the human articular disc, and higher requirements for estrogen receptors in the disc of women with TMD signs and symptoms. According to these authors, a concomitant presence of these receptors and specific levels of circulating hormones can lead to changes in the connective tissue of the TMJ disc, causing previous changes (Landi et al., 2005).

A previous systematic review (Berger et al., 2015) analyzed only estrogen and its relationship to pain processing in TMD, concluding that there is a need to conduct a study that analyzes its action on joint development, restitution, and metabolism, as well as its influence on regulatory mechanisms of pain.

This systematic survey of the literature aims to assess whether the relationship between changes in serum levels of progesterone and estrogen with the development and intensity of TMD in women.

\section{Methodology}

This systematic review was carried out in accordance with the statements of preferred reporting items for systematic analysis and meta-analysis protocols (PRISMA-P), with guidance from the Cochrane Handbook for Systematic Reviews. The protocol of systematic review is registered in the Prospective International Register of Systematic Reviews (PROSPERO), under number CRD42020198880.

The material for our study consisted of publications identified by advanced search performed independently by two authors using the databases PubMed (MEDLINE), PMC (PubMed), Cochrane, SciELO and Science Direct. Searches were also carried out on the Scopus and Embase bases. Gray literature was also consulted through Google Scholar. In order to identify relevant publications, a search was performed using the descriptors "Estrogen", "Temporomandibular Joint Disorder" and "Progesterone", identified by means of Health Sciences Descriptors (DeCS) and Medical Subject Headings (MeSH). Boolean operators (AND and OR) were used to combine the descriptors and enhance the search strategy through different combinations. A manual search of cross-references of original articles was also carried out to identify additional studies that could not be located in the electronic databases. These procedures were performed to avoid possible selection and publication bias. The search

Figure 1. Search strategy.

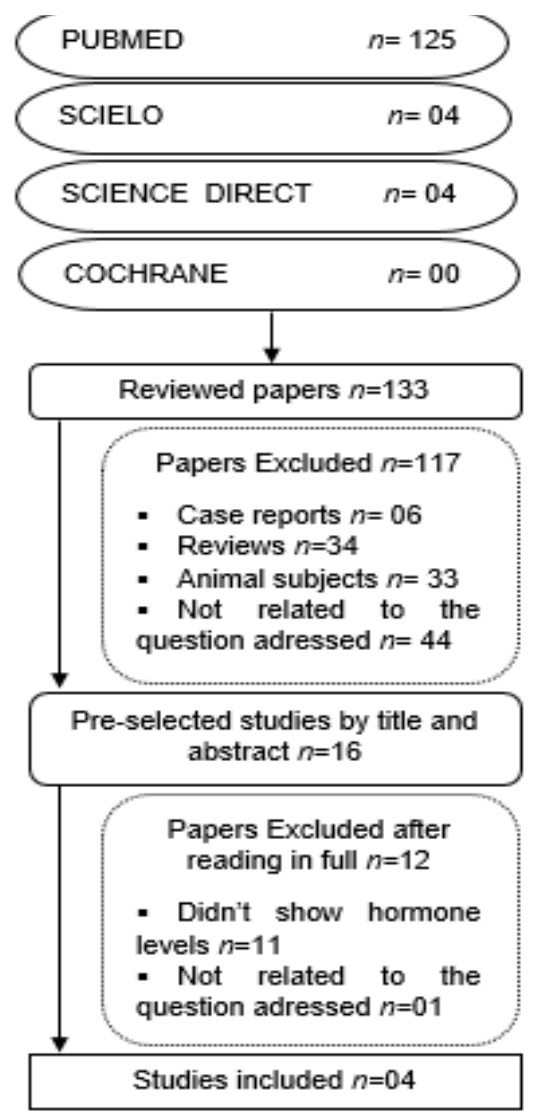

Source: Illustrations made by the authors themselver (2021). 
strategy is illustrated in the flowchart (Figure 1).

Data collection was carried out independently by two reviewers (RFFS and BDS), in three different phases. First, the reviewers discussed the eligibility criteria, in order to assess possible errors in the method. Then, the titles were read carefully to exclude articles outside the scope of this research. Studies in which the subject of interest could not be addressed were excluded. In phase 2, the abstracts of the other studies were analyzed independently by the two reviewers. At this stage, abstracts were excluded in which the subject of interest could not be addressed, literature reviews, case reports, animal and/or in vitro studies and studies without quantitative assessment of hormone levels. Inter-examiner agreement was assessed using the Kappa statistic, with a total of $10 \%$ and $90 \%$ of the studies evaluated in phases 1 and 2 , obtaining a strong agreement $(\mathrm{K} \geq$ 1.00 and $\mathrm{K} \geq 0.95$ ), respectively, confirming the reproducibility and reliability of the evaluation. In phase 3 , the other articles had their full text evaluated and their reference lists were carefully read to identify studies that could not be located. Then, the articles were evaluated to see if they met the other eligibility criteria. Studies in which the relationship between hormonal variations and TMD were not measured using quantitative serological tests were excluded. After evaluation, 4 studies were included. In situations where a mutual agreement was not reached between the two reviewers, a third reviewer (JRCQ) was involved to make a final decision. The rejected studies and the reasons for their exclusion were recorded in Table 1.

Table 1. List of Excluded Studies.

\begin{tabular}{|c|c|}
\hline $\begin{array}{l}\text { REASON FOR } \\
\text { EXCLUSION }\end{array}$ & FIRST AUTHOR \\
\hline Case reports & $\begin{array}{l}\text { Aneiros-Guerrero et al. 2011; Soni et al.2018; Kayipmaz et. al., 2019; Koumarianou et. al., } \\
\text { 2016; Stefanaki et. al., 2020; Rohan et. al., 2014. }\end{array}$ \\
\hline Reviews & $\begin{array}{l}\text { Fietz, 2018; Stinson et al. 2019; Farage, 2010; Lee et al. 2017; Sinno et al. 2011; Johnston } \\
\text { et. al., 2015; Lucaccioni et. al., 2020; Chukhlovin, 2015; Dussor et. al., 2018; Ratner et. al., } \\
\text { 2019; Casarini et. al., 2011; Szymańska et al., 2018; Landomiel et. al., 2019; Zhou et. al., } \\
\text { 2019; Aniogo et. al., 2019; Lee \& Judge, 2017; Roi et. al., 2019; Pani et. al., 2010; Pasquier } \\
\text { et. al., 2014; Al-Bashaireh et. al., 2018; Jones \& George, 2014; Ulloa-Aguirre et. al., 2018; } \\
\text { Janeček \& Dabrowska, 2019; Jani et. al., 2014; Kanherkar et. al., 2017; Detamore et. al., } \\
\text { 2007; Köck et. al., 2007; Rogers, 2009; Al et.al., 2018; Hukins, 2006; Rawn \& Cross, 2008; } \\
\text { Taatjes \& Roth, 2005; Kreeger, 2001; Di Pietro et. al., 2002. }\end{array}$ \\
\hline Animal subjects & $\begin{array}{l}\text { Park et. al. 2019; Siegel et al. 2012; Xue et al. 2017; Park et. al.2019; Wang et al. 2013; } \\
\text { Bootelho et. al, 2010; Robinson et. al, 2018; Xin et. al., 2018; Ghadami et. al., 2010; Bi et. } \\
\text { al., 2017; Rollick et. al., 2018; De Moraes et. al., 2012; Mason et. al. 2017; Ghadami et. al., } \\
\text { 2012; Bond et. al, 2019; Fu et. al., 2018; Peterson et. al., 2016; Kuyinu et. al., 2016; Munier } \\
\text { et. al, 2016; Driessen et. al., 2014; Yasuo et. al., 2000; Kapila et. al., 2009; Fischer et. al., } \\
\text { 2008; Wang et. al., 2009; Fischer et a.1, 2007; Abubaker et. al., 1996; Hashem et. al, 2006; } \\
\text { Puri et. al., 2009; Eikermann-Haerter et. al., 2009; Ceccarelli et. al., 2003; Schütz et. al., } \\
\text { 2009; D'Hooghe et. al., 2009; Watkin et. al., 2008. }\end{array}$ \\
\hline No hormone levels & $\begin{array}{l}\text { Lora et. al., 2016; Farzin et. al., 2018; Ribeiro-Dasilva et. al., 2017; Ungor et. al., 2014; } \\
\text { LeResche et. al., 2013; Sherman et. al., 2005; Mayoral et. al., 2013; Turner et al., 2011; } \\
\text { Wise et. al., 2000; Abubaker et. al., } 1993\end{array}$ \\
\hline
\end{tabular}




\begin{tabular}{c|l}
\hline & \\
& $\begin{array}{l}\text { Sahu et al. 2019; Hajati et al. 2010; Bernier et al. 2011; Sahu et al. 2019; Wieckiewicz et } \\
\text { al. 2014; Patil, 2013; Kumar et. al., 2017; Magri et. al., 2018; Turcio et. al., 2015; } \\
\text { Sundström Poromaa et. al., 2019; Hajati et. al., 2010; Rezaii et. al., 2010; Aneja et. al., } \\
\text { 2017; Gupta; Archarya, 2016; Cheng et. al., 2013; Devo \& Leslie, 2013; Olama et. al., 2015; } \\
\text { Kunimoto; Bajorath, 2017; Casarini et. al., 2018; Licausi et. al.,2013; Rodríguez-Razón et. } \\
\text { al., 2018; Solzak et. al., 2017; Chasombat et. al., 2013; Brellenthin et. al., 2017; Ergün et. } \\
\text { al., 2015; Hizjr et. al., 2017; Mihaljevic et. al., 2016; Wijaya et. al., 2017; Rebholz et. al., } \\
\text { 2018; Peeraer et. al., 2015; Bathen et. al., 2013; Pasquier et. al., 2012; Maleki et. al, 2012; } \\
\text { Nekora et. al., 2008; Watkin et. al., 2008; Penetar et. al., 2009; Lima et. al., 2019; Peräkylä } \\
\text { et. al., 2009; Ahmed et. al., 2000; Reiman et. ao, 1996; Casarsa et. al., 2008; Mullins et. al., } \\
\text { 2007; Cauwe et. al., 2007; Soydan et. al., 2014. }\end{array}$ \\
\hline
\end{tabular}

Source: Authors (2021).

The scoring questions were based on the "Cochrane Handbook for Systematic Reviews of Interventions 4.2.6 Updated September 2006" (Higgins \& Green, 2018), on the PRISMA 2009 checklist (Liberati et al. 2009), "Advice on how to write a systematic review. JM Wardlaw. 14th January 2010", and the quality assessment tool for diagnostic accuracy studies (QUADAS) recommended by Cochrane. The studies were scored according to the questions presented in Table 2. Each article was scored from 0 to 2 and the scores were added up. The methodology of each selected article was evaluated and the information included in the table. Scores from 0 to 8 were classified as a low evidence value, while scores from 9 to 11 and 12 to 14 were classified as a moderate and high evidence value respectively.

Table 2. Methodological evaluation of selected works.

\begin{tabular}{|c|c|c|}
\hline QUESTIONS & METHODS & SCORING \\
\hline Q1 & $\begin{array}{l}\text { Sample } \\
\text { size }\end{array}$ & $\begin{array}{ll}. & 0-9-\mathbf{0} \text { pts } \\
. & 10-99-\mathbf{1} \mathbf{p t} \\
. \quad & >100-\mathbf{2} \mathbf{p t s}\end{array}$ \\
\hline Q2 & $\begin{array}{l}\text { Control } \\
\text { group }\end{array}$ & $\begin{array}{l}\text { - } \quad \text { none }-\mathbf{0} \text { pts } \\
\text { - } \quad \text { present }-\mathbf{2} \text { pts }\end{array}$ \\
\hline Q3 & $\begin{array}{l}\text { Inclusion } \\
\text { criteria }\end{array}$ & $\begin{array}{ll}\text { - } & \text { none }-\mathbf{0} \mathbf{p t s} \\
\text { - } & \text { present, not restricted to one form of } \\
\text { - } & \text { restricted to one form of TMD }-\mathbf{2} \text { pts }\end{array}$ \\
\hline Q4 & $\begin{array}{l}\text { Exclusion } \\
\text { criteria }\end{array}$ & $\begin{array}{l}\text { - } \text { none }-\mathbf{0} \text { pts } \\
\text { - } \quad \text { concomitant pain disorders OR other } \\
\text { medications use OR systemic disease OR lactating OR } \\
\text { pregnancy }-\mathbf{1} \mathbf{~ p t} \\
\text { - } \quad \text { concomitant pain disorders AND other } \\
\text { medications use AND systemic disease AND lactating } \\
\text { AND pregnancy } \mathbf{2} \mathbf{~ p t s}\end{array}$ \\
\hline Q5 & $\begin{array}{l}\text { Use of } \\
\text { standardized } \\
\text { examination } \\
\text { protocol }\end{array}$ & $\begin{array}{l}\text { - } \quad \text { none }-\mathbf{0} \text { pts } \\
\text { other protocols - 1pt RDC/TMD - } \mathbf{2} \text { pts }\end{array}$ \\
\hline Q6 & $\begin{array}{c}\text { Estrogen and } \\
\text { Progesterone } \\
\text { level assessment }\end{array}$ & $\begin{array}{l}\text { - } \text { none - } \mathbf{0 ~ p t} \\
\text { - blood or saliva assessment not based on phases of } \\
\text { - } \quad \text { the menstrual cycle }-\mathbf{1} \mathbf{~ p t} \\
\text { blood or saliva assessment based on phases of the } \\
\text { menstrual cicle- } \mathbf{2} \text { pts }\end{array}$ \\
\hline Q7 & $\begin{array}{l}\text { Conflict of } \\
\text { interest }\end{array}$ & $\begin{array}{ll}\text { - } & \text { present }-\mathbf{0} \text { pts } \\
\text { - } & \text { no data }-\mathbf{1 p t} \\
\text { - } & \text { none }-\mathbf{2} \text { pts }\end{array}$ \\
\hline
\end{tabular}


Research, Society and Development, v. 10, n. 6, e21310615654, 2021

(CC BY 4.0) | ISSN 2525-3409 | DOI: http://dx.doi.org/10.33448/rsd-v10i6.15654

\begin{tabular}{|c|c|c|c|c|c|c|c|c|c|}
\hline \multirow{2}{*}{ AUTHORS } & \multirow{2}{*}{ TITLE } & \multicolumn{7}{|c|}{ SCORING } & \multirow[t]{2}{*}{ TOTAL } \\
\hline & & Q1 & Q2 & Q3 & Q4 & Q5 & Q6 & Q7 & \\
\hline $\begin{array}{l}\text { Patil et al. } \\
\quad(2015)\end{array}$ & $\begin{array}{l}\text { Role of female } \\
\text { reproductive hormones } \\
\text { estrogen and } \\
\text { progesterone in } \\
\text { temporomandibular } \\
\text { disorder in female } \\
\text { patients }\end{array}$ & 2 & 0 & 1 & 2 & 1 & 1 & 2 & 9 \\
\hline $\begin{array}{l}\text { LeResche et al. } \\
\quad(2005)\end{array}$ & $\begin{array}{l}\text { Musculoskeletal } \\
\text { orofacial pain and other } \\
\text { signs and symptoms of } \\
\text { temporomandibular } \\
\text { disorders during } \\
\text { pregnancy: a } \\
\text { prospective study. }\end{array}$ & 1 & 2 & 1 & 0 & 2 & 1 & 2 & 9 \\
\hline $\begin{array}{l}\text { Landi et.al. } \\
\quad \text { (2005) }\end{array}$ & $\begin{array}{c}\text { Sexual hormone serum } \\
\text { levels and } \\
\text { temporomandibular } \\
\text { disorders }\end{array}$ & 1 & 2 & 1 & 0 & 2 & 2 & 2 & 10 \\
\hline $\begin{array}{l}\text { Madani et al. } \\
\quad(2013)\end{array}$ & $\begin{array}{l}\text { A cross-sectional study } \\
\text { of the relationship } \\
\text { between serum sexual } \\
\text { hormone levels and } \\
\text { internal derangement of } \\
\text { temporomandibular } \\
\text { joint. }\end{array}$ & 2 & 2 & 2 & 2 & 2 & 2 & 2 & 14 \\
\hline
\end{tabular}

\section{Results}

In general, few clinical trials have been developed comparing this relationship, although there are several reviews and studies in animals addressing the topic. Analyzing this smaller amount, heterogeneity is perceived in relation to the method of diagnosis of the disease, as well as the complementary exam and the phase to be performed the hormonal count.

Regarding diagnosis among patients, only one study (Patil et al., 2015) did not use the RDC / TMD (Diagnostic Criteria for Research on Temporomandibular Dysfunction) as a method, addressing the anamnesis questionnaire proposed by Fonseca et al. 1994. The analysis of hormone levels was performed mainly through blood collection, except for one case (LeResche et al., 2005) where the entire unstimulated saliva was collected for this purpose, as shown in Table 3 below. 
Table 3. Objectives and methods of the studies.

\begin{tabular}{|c|c|c|}
\hline STUDY & TITLE & AIM AND METHOD OF THE STUDY \\
\hline $\begin{array}{l}\text { Patil et al. } \\
\quad \text { (2015) }\end{array}$ & $\begin{array}{c}\text { Role of female reproductive } \\
\text { hormones estrogen and progesterone } \\
\text { in temporomandibular disorder in } \\
\text { female patients. }\end{array}$ & $\begin{array}{l}\text { - Aim of study: } \\
\text { The aim of the present study is to investigate the role of female } \\
\text { reproductive hormones estrogen and progesterone in temporomandibular } \\
\text { disorder (TMD) in female patients. } \\
\text { - Compared variables: } \\
\text { Estrogen and Progesterone levels. } \\
\text { - TMD diagnosis method: } \\
\text { Questionnaire proposed by Fonseca } \\
\text { - Hormone level assessment: } \\
\text { Blood sample }\end{array}$ \\
\hline $\begin{array}{l}\text { Madani } e t \\
\text { al. } \\
(2013)\end{array}$ & $\begin{array}{l}\text { A cross-sectional study of the } \\
\text { relationship between serum sexual } \\
\text { hormone levels and internal } \\
\text { derangement of temporomandibular } \\
\text { joint. }\end{array}$ & $\begin{array}{l}\text { - Aim of study: } \\
\text { The aim of this study was to evaluate } 17 \mathrm{~b} \text {-oestradiol and progesterone } \\
\text { serum levels in menstruating women affected by internal derangement of the } \\
\text { TMJ. } \\
\text { - Compared variables: } \\
\text { Estrogen and Progesterone levels. } \\
\text { - TMD diagnosis method: } \\
\text { Clinical examination according to RDC/TMD } \\
\text { - Hormone level assessment: } \\
\text { Blood sample }\end{array}$ \\
\hline $\begin{array}{l}\text { Landi et al. } \\
\quad(2005)\end{array}$ & $\begin{array}{c}\text { Sexual hormone serum levels and } \\
\text { temporomandibular disorders. A } \\
\text { preliminary study. }\end{array}$ & $\begin{array}{l}\text { - Aim of study: } \\
\text { The aim of the present study was to investigate the role of sexual } \\
\text { hormones in a young adult population affected by articular forms of } \\
\text { temporomandibular disorders (TMD), measuring 17b-estradiol and } \\
\text { progesterone serum levels. } \\
\text { Compared variables: } \\
\text { Estrogen and Progesterone levels. } \\
\text { - TMD diagnosis method: } \\
\text { Clinical examination according to RDC/TMD } \\
\text { Bormone level assessment: } \\
\text { Blood sample }\end{array}$ \\
\hline $\begin{array}{l}\text { LeResche } \\
\text { et al. } \\
\text { (2005) }\end{array}$ & $\begin{array}{l}\text { Musculoskeletal orofacial pain and } \\
\text { other signs and symptoms of } \\
\text { temporomandibular disorders during } \\
\text { pregnancy: a prospective study. }\end{array}$ & $\begin{array}{l}\text { - Aim of study: } \\
\text { To describe the course of reported musculoskeletal pain in the } \\
\text { temporomandibular region and other signs and symptoms of } \\
\text { temporomandibular disorders (TMD) as well as psychological distress over the } \\
\text { course of pregnancy and one year postpartum. } \\
\text { - Compared variables: } \\
\text { Musculoskeletal pain in the temporomandibular region } \\
\text { Estrogen levels (measured in the 3rd, 6th and 9th month of pregnancy and one } \\
\text { year postpartum) } \\
\text { Pain severity (the Graded Chronic Pain Scale) } \\
\text { - TMD diagnosis method: } \\
\text { Clinical examination according to RDC/TMD } \\
\text { Hormone level assessment: } \\
\text { Unstimulated saliva samples }\end{array}$ \\
\hline
\end{tabular}

Source: Authors.

The relationship between estrogen levels was observed in three studies (Patil et al., 2015; Landi et al., 2005; LeResche et al., 2005), while another study (Madani et al., 2013) did not showed altering estrogen levels in women who had crackles when compared to the control group. The association of progesterone has also been found in three studies (Patil et al., 2015; Madani et al., 2013; LeResche et al., 2005). One (Landi et al., 2005) of them found no variation in serum progesterone levels, as shown in Table 4. 
Table 4. Characteristics of the included studies and analysis of the relationship between hormonal levels.

\begin{tabular}{|c|c|c|c|c|c|c|c|}
\hline \multirow{2}{*}{ STUDY } & \multirow{2}{*}{ DESING } & \multirow{2}{*}{$\mathbf{N}$} & \multirow{2}{*}{ AGE } & \multicolumn{2}{|c|}{ HORMONAL LEVELS } & \multicolumn{2}{|c|}{$\begin{array}{l}\text { RELATIONSHIP } \\
\text { WITH TMD }\end{array}$} \\
\hline & & & & ESTROGEN (E) & PROGESTERONE (P) & $\mathbf{E}$ & $\mathbf{P}$ \\
\hline $\begin{array}{l}\text { Patil } \\
\text { et. al. } \\
(2015)\end{array}$ & $\begin{array}{l}\text { Case-control } \\
\text { study }\end{array}$ & 200 & $\begin{array}{l}\text { 14-40 years } \\
(\text { mean } \pm \\
\text { standard } \\
\text { deviation = } \\
24 \pm 8)\end{array}$ & $\begin{array}{c}\text { Severe cases: } \\
444,2 \pm 3,57 \mathrm{pg} / \mathrm{mL} \\
\text { Moderate cases: } \\
264,5 \pm 2,23 \mathrm{pg} / \mathrm{mL} \\
\text { Mild cases: } \\
199,8 \pm 3,46 \mathrm{pg} / \mathrm{mL}\end{array}$ & $\begin{array}{c}\text { Severe cases: } \\
1,88 \pm 41,9 \mathrm{ng} / \mathrm{mL} \\
\text { Moderate cases: } \\
1,64 \pm 33,2 \mathrm{ng} / \mathrm{mL} \\
\text { Mild cases: } \\
1,52 \pm 34,7 \mathrm{ng} / \mathrm{mL}\end{array}$ & YES & YES \\
\hline $\begin{array}{c}\text { Madani et. } \\
\text { al. } \\
(2013)\end{array}$ & $\begin{array}{l}\text { Cross- } \\
\text { sectional } \\
\text { study }\end{array}$ & $\begin{array}{l}\text { TMD } \\
\text { group: } 47 \\
\text { Control } \\
\text { group: } 95\end{array}$ & $\begin{array}{l}\text { TMD group: } \\
\begin{array}{l}28.5 \pm 5.4 \\
\text { Control } \\
\text { group: } \\
31.0 \pm 7.2\end{array}\end{array}$ & $\begin{array}{c}\text { TMD group: } \\
164 \pm 104.6 \mathrm{pg} / \mathrm{mL}^{-1} \\
(\text { mean } \pm \text { s.d) } \\
\text { Group control: } \\
162 \pm 129.9 \mathrm{pg} / \mathrm{mL}^{-1}\end{array}$ & $\begin{array}{c}\text { TMD group: } \\
8,4 \pm 6,8 \mathrm{ng} / \mathrm{mL}^{-1} \\
\text { Group control: } \\
11,6 \pm 10,4 \mathrm{ng} / \mathrm{mL}^{-1}\end{array}$ & NO & YES \\
\hline $\begin{array}{l}\text { Landi } \\
\text { et. al. } \\
(2005)\end{array}$ & $\begin{array}{l}\text { Case-control } \\
\text { study }\end{array}$ & $\begin{array}{l}\text { TMD } \\
\text { group: } 40 \\
\text { (20 women } \\
+20 \text { men) }\end{array}$ & $\begin{array}{l}\text { TMD group: } \\
\text { Women: } 25,6 \\
\pm 4,1 ; \\
\text { Men: } 24,8 \pm \\
3,1 \\
\\
\\
\\
\text { Control } \\
\text { group: } \\
\text { Women: } 22,3 \\
\pm 1,5 ; \\
\text { Men: } 24,4 \pm \\
2,3\end{array}$ & $\begin{array}{l}\text { Follicular Phase } \\
\text { TMD group } \\
\text { (woman): } 112,0+ \\
\text { 42,6pg/mL } \\
\text { (woman): } \\
\text { (woup Control } \\
\text { 139,0 + 18,4pg/mL } \\
\\
\text { Luteal Phase: } \\
\text { TMD group } \\
\text { (woman): } \\
\text { 203,0 + 71,1pg/mL } \\
\text { Group Control } \\
\text { (woman): } \\
110,6+44,2 \mathrm{pg} / \mathrm{mL}\end{array}$ & $\begin{array}{c}\text { Follicular Phase } \\
\text { TMD group (woman): } \\
\text { 1,08 + 0,30ng/mL } \\
\text { Group Control (woman): } \\
0,97+0,25 \mathrm{ng} / \mathrm{mL} \\
\text { Luteal Phase: } \\
\text { TMD group (woman): } \\
\text { 14,10 + 3,70pg/mL } \\
\text { Group Control (woman): } \\
10,90+1,10 \mathrm{ng} / \mathrm{mL}\end{array}$ & YES & NO \\
\hline $\begin{array}{c}\text { LeResche } \\
\text { et. al. } \\
(2005)\end{array}$ & $\begin{array}{l}\text { Prospective } \\
\text { cohort study }\end{array}$ & $\begin{array}{c}\text { TMD } \\
\text { group: } 19 \\
\text { (pregnant } \\
\text { women) }\end{array}$ & $\begin{array}{c}\text { Study group: } \\
28.5 \pm 4.9 \\
\text { Control }\end{array}$ & $\begin{array}{l}\text { 3-Month (Both } \\
\text { groups): } 6 \mathrm{pmol} / \mathrm{L} \text { to } \\
72 \mathrm{pmol} / \mathrm{L} ; \\
6 \text { TO 9-Month (Both }\end{array}$ & $\begin{array}{c}\text { 3-Month (Both groups): } \\
201 \mathrm{pmol} / \mathrm{L} \text { to } \\
\text { 1,812pmol/L; } \\
6 \text { TO 9-Month (Both } \\
\text { groups): mean 535pmol/L }\end{array}$ & YES & YES \\
\hline
\end{tabular}




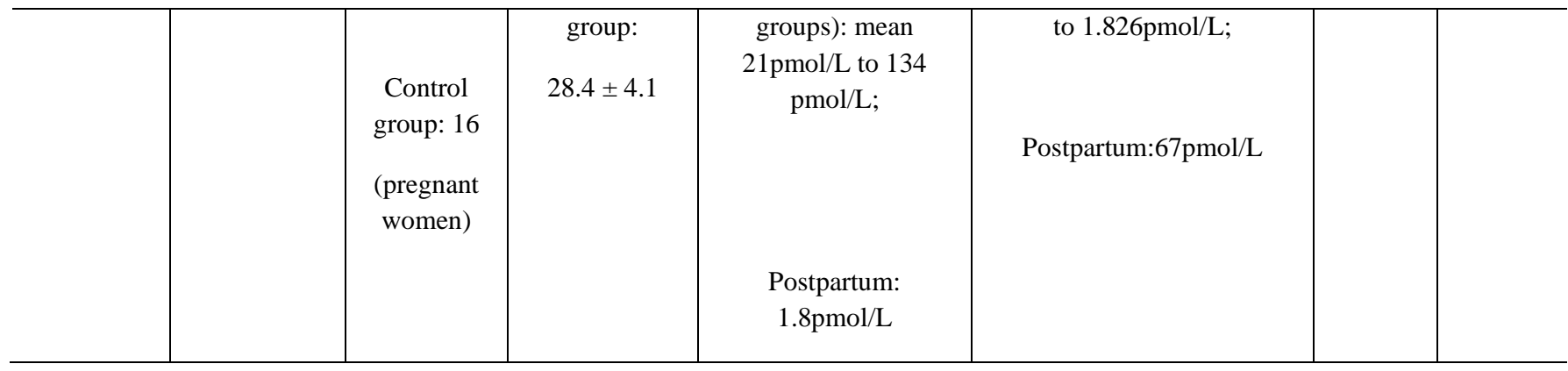

Source: Authors.

Regarding the classification of evidence, analyzing the questions and the questions scores found in Table 2, it is possible to classify most studies (Patil et al., 2015; Landi et al., 2005; LeResche et al., 2005) with moderate value, while one with high value (Madani et al., 2013). However, the lack of alignment between studies makes it difficult to associate the variations present in the configurations as in the hormonal processes.

It was not possible to state through the selected researches whether changes in the levels of progesterone and estrogen can predispose women to the development of the disease or be related to the severity of existing cases; but that there is a great possibility in this relationship.

\section{Discussion}

Examining the multifactorial character of Temporomandibular Dysfunction and its broad clinical picture of signs and symptoms, several criteria make its diagnosis possible. The RDC / TMD, used by most selected studies (Landi et al., 2005; Madani et al., 2013; LeResche et al., 2005), is one of the diagnostic classifications available in the broadest literature and accepted in clinical research, with acceptable levels of reliability to assess the standardized form up to clinical subtypes myogenic and atherogenic - from the disease (Chaves, Oliveira \& Grossi, 2008). The Fonseca Questionnaire and Anamnesis Index (Fonseca et al., 1994), used in one of the studies (Patil et al., 2015), is indicated to evaluate mainly the severity of symptomatic conditions, being indicated for population epidemiological studies due to its ease of application, not being very usual for trials clinical, considering that it does not offer diagnostic classification (Chaves, Oliveira \& Grossi, 2008).

Serum hormone levels were measured by collecting blood (Patil et al., 2015; Landi et al., 2005; Madani et al., 2013) and saliva (LeResche et al., 2005). Saliva can be presented as a simplified and non-invasive source for the collection of samples for hormonal analysis and, although not yet clinically reliable, it has been widely used to assess the concentration of steroids, polypeptides, antibodies, alcohol, and drugs illicit use (Puhakkra \& Peltola, 2020). Its use in substitution to the traditional method of laboratory analysis presents as a limitation the difficulty of detecting some proteins that present themselves in low concentration in the salivary fluid (Rilling et al., 1996; Ghiciuc et al., 2016).

The distribution of age and gender in cases of orofacial pain suggests a possible association between its pathogenesis and estrogen (Ghiciuc et al., 2016). Evidence shows that its levels are not only related to pain modulation but the development and restitution of the TMJ and associated structures. Besides, it can influence the synthesis of collagen and elastin, which make up the articular disc (Gupta et al., 2011 Fenzi \& Rizzuto, 2001; Tashiro, Okamoto \& Bereiter, 2011).

Among the studies reviewed, the only one did not describe a relationship between estrogen and TMD (Madani et al., 2013). In it, women in the menstrual period with disorders in the temporomandibular joint were evaluated regarding the crackling resulting from the wear of the articular disc where there was no significant difference between the control group and those with values below or above normal. This result differs from the other studies reviewed (Patil et al., 2015; Landi et al., 2005; LeResche et al., 2005) and also from studies carried out in animals, in which the TMJ of ovariectomized and non- 
ovariectomized rats with and without hormonal supplementation was evaluated, demonstrating that estrogen in physiological concentration plays a role in joint remodeling (Yasuoka et al., 2000). Other studies (Kamiya et al., 2013; Abdrabuh \& Balion, 2020; Kou et al., 2011) with similar methodology also reported that the deficiency of this hormone caused degradation of the articular disc and the cartilaginous layer of the mandibular condyle in their samples.

The possible relationship between progesterone and TMD cases occurred when observing that pregnant women have fewer symptoms than non-pregnant women (LeResche et al., 2005). This hormone is involved in the modulation of inflammatory processes and is overexpressed during pregnancy (Xue et al., 2017). Three reviewed papers analyzed and confirmed that serum progesterone variations are related to the inflammatory severity of TMD (Patil et al., 2015; Madani et al., 2013; LeResche et al., 2005).

Animal studies (Hormung et al., 2020; Kou et al., 2011) show that progesterone can offer continuous relief in orofacial pain and that, in cases of reduced levels, an increase in the inflammatory process was triggered; while its maintenance at normal rates shows a reduction in edema and pain. Also, a systematic review (Berger et al., 2015) that analyzed only the relationship of estrogen points not only to the deficiency and limitations of the studies selected in its selection but also to inconsistency between its results, and even though there is stagnation in this area of knowledge, even there is still no precise thing about the relationship. These data corroborate those that were addressed, however, in this review we also take into account the role of progesterone shown in research.

\section{Conclusion}

The studies developed that addressed the possible relationship between estrogen and progesterone with the highest incidence of Temporomandibular Disorder in women present divergences between them, ranging from the experimental design to the same result. Therefore, it is not possible to clarify whether there is, in fact, a relationship between hormonal variation and the greater female predisposition to the development and severity of the disease. However, even with the strong evidence produced by them, this review suggests the realization of new clinical trials that separate the different hormonal fluctuations that range from reproductive age to post-menopause so that a survey with methodological quality studies is possible.

\section{References}

Abdrabuh A., Baljon K., et al. (2020). Impact of estrogen therapy on temporomandibular joints of rats: Histological and hormone analytical study. Saudi Dental Journal 1020-1029. https://doi.org/10.1016/j.sdentj.2020.07.006

Bartley, E. J., \& Fillingim, R. B. (2013). Sex differences in pain: a brief review of clinical and experimental findings. British journal of anaesthesia, 111(1), 52-58. https://doi.org/10.1093/bja/aet127.

Benoliel R., Sharav Y. Chronic orofacial pain. Curr Pain Headache Rep. (2010) 14(1):33-40. 10.1007/s11916-009-0085-y.

Berger, M., Szalewski, L., Bakalczuk, M., Bakalczuk, G., Bakalczuk, S., \& Szkutnik, J. (2015). Association between estrogen levels and temporomandibular disorders: a systematic literature review. Przeglad menopauzalny = Menopause review, 14(4), 260-270. https://doi.org/10.5114/pm.2015.56538.

Chaves T. C., Oliveira A. M. S., \& Grossi D. B. (2008). Principais instrumentos para avaliação da disfunção temporomandibular, parte II: critérios diagnósticos; uma contribuição para a prática clínica e de pesquisa. Fisioterapia e Pesquisa, 15(1), 101-106. https://doi.org/10.1590/S180929502008000100016 .

De Rossi, S. S., Greenberg, M. S., Liu, F., \& Steinkeler, A. (2014). Temporomandibular disorders: evaluation and management. The Medical clinics of North America, 98(6), 1353-1384. https://doi.org/10.1016/j.mcna.2014.08.009.

Fenzi, F., \& Rizzzuto, N. (2011). Estrogen receptors localization in the spinal trigeminal nucleus: an immunohistochemical study in humans. European journal of pain.15(10), 1002-1007. https://doi.org/10.1016/j.ejpain.2011.05.003.

Fonseca D. M., Bonfate G., Valle A. L., \& Freitas S. F. T. (1994). Diagnóstico pela anamnese da disfunção craniomandibular. Rev gaucha odontol (42):23-28.

Ghiciuc, C. M., Dima-Cozma, L. C., Bercea, R. M. L., Catalina E., Mihaescu, T., Cozma, S., \& Patacchioli, Francesca R. (2016). Desequilíbrio na proporção salivar diurna de testosterona/cortisol em homens com apneia obstrutiva do sono grave: um estudo observacional. Brazilian journal of otorhinolaryngology, 82(5), 529-535. https://doi.org/10.1016/j.bjorl.2015.09.004. 
Gupta, S., McCarson, K. E., Welch, K. M., \& Berman, N. E. (2011). Mechanisms of pain modulation by sex hormones in migraine. Headache, 51(6), 905922. https://doi.org/10.1111/j.1526-4610.2011.01908.x.

Higgins, J. P. T. \& Green S. (2018) Cochrane Handbook for Systematic Reviews of Interventions Version 5.1.0 )2011), The Cochrane Collaboration, http://handbook.cochrane.org.

Hornung R. S., Benton W.L., Tongkhuya S., Uphouse L., Kramer P. R., \& Averitt D. L. (2020). Progesterone and Allopregnanolone Rapidly Attenuate Estrogen-Associated Mechanical Allodynia in Rats with Persistent Temporomandibular Joint Inflammation. Front Integr Neurosci. 14:26. https://doi.org/10.3389/fnint.2020.00026.

Joseph R., Rahena A., Hassan N., Glen H., \& James W. (2019). Epidemiology of Temporomandibular Disorder in the General Population: a Systematic Review. Adv dent \& oral health. 10(3): 555787. 10.19080/ADOH.2019.10.555787.

Kamiya Y.J., Chen M., Xu A., Utreja T., Choi H., Drissi S., \& Wadhwa J. (2013). Increased mandibular condylar growth in mice with estrogen receptor beta deficiency. J. Bone. Miner. Res. 28:1127-1134. https://doi.org/10.1002/jbmr.1835

Kou, X. X., Wu, Y. W., Ding, Y., Hao, T., Bi, R. Y., Gan, Y. H., \& Ma, X. (2011). 17ß-estradiol aggravates temporomandibular joint inflammation through the NF-kB pathway in ovariectomized rats. Arthritis and rheumatism, 63(7), 1888-1897. https://doi.org/10.1002/art.30334.

Landi, N., Lombardi, I., Manfredini, D., Casarosa, E., Biondi, K., Gabbanini, M., \& Bosco, M. (2005). Sexual hormone serum levels and temporomandibular disorders. A preliminary study. Gynecological endocrinology : the official journal of the International Society of Gynecological Endocrinology, 20(2), 99103. https://doi.org/10.1080/09513590400021136.

LeResche, L., Sherman, J. J., Huggins, K., Saunders, K., Mancl, L. A., Lentz, G., \& Dworkin, S. F. (2005). Musculoskeletal orofacial pain and other signs and symptoms of temporomandibular disorders during pregnancy: a prospective study. Journal of orofacial pain, 19(3), 193-201.

Liberati, A., Altman, D. G., Tetzlaff, J., Mulrow, C., Gøtzsche, P. C., Ioannidis, J. P., Clarke, M., Devereaux, P. J., Kleijnen, J., \& Moher, D. (2009). The PRISMA statement for reporting systematic reviews and meta-analyses of studies that evaluate healthcare interventions: explanation and elaboration. $B M J$ (Clinical research ed.), 339, b2700. https://doi.org/10.1136/bmj.b2700.

Lu, Y., Li, Z., Li, H. J., Du, D., Wang, L. P., Yu, L. H., Burnstock, G., Chen, A., \& Ma, B. (2012). A comparative study of the effect of $17 \beta$-estradiol and estriol on peripheral pain behavior in rats. Steroids, 77(3), 241-249. https://doi.org/10.1016/j.steroids.2011.11.011.

Madani, A. S., Shamsian, A. A., Hedayati-Moghaddam, M. R., Fathi-Moghadam, F., Sabooni, M. R., Mirmortazavi, A., \& Golmohamadi, M. (2013). A crosssectional study of the relationship between serum sexual hormone levels and internal derangement of temporomandibular joint. Journal of oral rehabilitation, 40(8), 569-573. https://doi.org/10.1111/joor.12074.

Maurer, A. J., Lissounov, A., Knezevic, I., Candido, K. D., \& Knezevic, N. N. (2016). Pain and sex hormones: a review of current understanding. Pain management, 6(3), 285-296. https://doi.org/10.2217/pmt-2015-0002.

Miyazaki, R., \& Yamamoto, T. (2009). Sex and/or gender differences in pain. Masui. The Japanese journal of anesthesiology, 58(1), 34-39.

Patil S.R., Yadav N., Mousa M. A., Alzwiri A., Kassab M., Sahu R., \& Chuggani S (2015). Role of female reproductive hormones estrogen and progesterone in temporomandibular disorder in female patients. J oral res rev (7):41-3. doi: 10.4103/2249-4987.172492.

Puhakka, I., \& Peltola, M. J. (2020). Salivary cortisol reactivity to psychological stressors in infancy: A meta-analysis. Psychoneuroendocrinology, 115, 104603. https://doi.org/10.1016/j.psyneuen.2020.104603.

Reiter, S., Emodi-Perlman, A., Goldsmith, C., Friedman-Rubin, P., \& Winocur, E. (2015). Comorbidity between depression and anxiety in patients with temporomandibular disorders according to the research diagnostic criteria for temporomandibular disorders. Journal of oral \& facial pain and headache, 29(2), 135-143. https://doi.org/10.11607/ofph.1297.

Rilling, J. K., Worthman, C. M., Campbell, B. C., Stallings, J. F., \& Mbizva, M. (1996). Ratios of plasma and salivary testo sterone throughout puberty: production versus bioavailability. Steroids, 61(6), 374-378. https://doi.org/10.1016/0039-128x(96)00043-8.

Shedden Mora, M., Weber, D., Borkowski, S., \& Rief, W. (2012). Nocturnal masseter muscle activity is related to symptoms and somatization in temporomandibular disorders. Journal of psychosomatic research, 73(4), 307-312.

Stinson C., Bellinger L. L., Puri J., Ahuja N., Bender S. D., \& Kramer P. R. (2019). Estrogenic effects on temporomandibular disorder and pain. J appl biobehav res e12164. doi:10.1111/jabr.12164.

Tashiro A., \& Okamoro K. B. (2011). Rapid estrogenic effects on TMJ responsive brainstem neurons.. J Dent Res. 91(2):210-4. https://doi.org/10.1177/0022034511428156

Torres-Chávez, K. E., Sanfins, J. M., Clemente-Napimoga, J. T., Pelegrini-Da-Silva, A., Parada, C. A., Fischer, L., \& Tambeli, C. H. (2012). Effect of gonadal steroid hormones on formalin-induced temporomandibular joint inflammation. European journal of pain (London, England), 16(2), 204-216. https://doi.org/10.1016/j.ejpain.2011.06.007.

Wahid, A., Mian, F. I., Razzaq, A., Bokhari, S., Kaukab, T., et al. (2014) Prevalence and severity of temporomandibular disorders (TMD) in undergraduate medical students using Fonseca's questionnaire. Pak oral dent $j$ 34(1), 38-41.

Wieckiewicz, M., Grychowska, N., Wojciechowski, K., Pelc, A., Augustyniak, M., Sleboda, A., \& Zietek, M. (2014). Prevalence and correlation between TMD based on RDC/TMD diagnoses, oral parafunctions and psychoemotional stress in Polish university students. BioMed research international, 2014, 472346. https://doi.org/10.1155/2014/472346. 
Research, Society and Development, v. 10, n. 6, e21310615654, 2021

(CC BY 4.0) | ISSN 2525-3409 | DOI: http://dx.doi.org/10.33448/rsd-v10i6.15654

Xue X., Kou X., Li C., et al. (2017). Progesterone attenuates temporomandibular joint inflammation through inhibition of NF-kB pathway in ovariectomized rats. Sci Rep. (1):15334. https://doi.org/10.1038/s41598-017-15285-w.

Xue, X. T., Kou, X. X., Li, C. S., Bi, R. Y., Meng, Z., Wang, X. D., Zhou, Y. H., \& Gan, Y. H. (2017). Progesterone attenuates temporomandibular joint inflammation through inhibition of NF-kB pathway in ovariectomized rats. Scientific reports, 7(1), 15334. https://doi.org/10.1038/s41598-017-15285-w.

Yasuoka T., Nakashima M., Okuda T., Tatematsu N. (2000). Effect of estrogen replacement on temporomandibular joint remodeling in ovariectomized rats. $J$ Oral Maxillofac Surg. 58(2):189-197. https://doi.org/10.1016/s0278-2391(00)90337-9

Yu, S., Xing, X., Liang, S., Ma, Z., Li, F., Wang, M., \& Li, Y. (2009). Locally synthesized estrogen plays an important role in the development of TMD. Medical hypotheses, 72(6), 720-722. https://doi.org/10.1016/j.mehy.2008.11.043. 